This provisional PDF corresponds to the article as it appeared upon acceptance.

A copyedited and fully formatted version will be made available soon.

The final version may contain major or minor changes.

\title{
GEOGRAPHIC ENROLLMENT OF THE TOP 100 IN ATHLETICS RUNNING EVENTS FROM 1996 TO 2012
}

Andy MARC, Adrien SEDEAUD, Julien SCHIPMAN, Juliana Jacquemin ANTERO, Guillaume SAULIERE, Katrine Okholm KRYGER, Jean-François TOUSSAINT

J Sports Med Phys Fitness 2015 Dec 02 [Epub ahead of print]

\section{THE JOURNAL OF SPORTS MEDICINE AND PHYSICAL FITNESS}

Rivista di Medicina, Traumatologia e Psicologia dello

Sport pISSN 0022-4707 - eISSN 1827-1928

Article type: Original Article

The online version of this article is located at http://www.minervamedica.it

Subscription: Information about subscribing to Minerva Medica journals is online at: http://www.minervamedica.it/en/how-to-order-journals.php

Reprints and permissions: For information about reprints and permissions send an email to:

journals.dept@minervamedica.it - journals2.dept@minervamedica.it - journals6.dept@minervamedica.it 


\section{GEOGRAPHIC ENROLLMENT OF THE TOP 100 IN ATHLETICS RUNNING EVENTS FROM 1996 TO 2012}

Andy Marc ${ }^{1^{*}}$, Adrien Sedeaud ${ }^{1,2}$, Julien Schipman ${ }^{1}$, Juliana Antero Jacquemin ${ }^{1,2}$,Guillaume Saulière ${ }^{1,2}$, Katrine Okholm Kryger ${ }^{1,3}$, Jean-François Toussaint ${ }^{1,2,4}$

1 Institute for Research in Medicine and Epidemiology of Sport (IRMES), 11 avenue du Tremblay, 75012 Paris, FRANCE, irmes@insep.fr

${ }^{2}$ Paris-Descartes University, Sorbonne Paris Cité, 12 rue de l'école de médecine, 75006 Paris, FRANCE

3 Sports Technology Institute, Loughborough University, UK

${ }^{4}$ Center for Investigation in Medicine and Sport (CIMS), Hôtel-Dieu, Assistance Publique - Hôpitaux de Paris, 75004 Paris, FRANCE

${ }^{*}$ Corresponding author :

Andy MARC, 11 avenue du Tremblay 75012 Paris France, andy.marc@insep.fr, +33141744124

\section{Acknowledgments:}

The authors thank Katrine Okholm Kryger and Scott Del Vecchio for proofreading the manuscript and providing valuable critique and advice. 


\section{ABSTRACT:}

Purpose It is widely accepted in the literature that athletes of West African origins achieve the best sprint performances; while, athletes originating from East Africa are the most efficient at long distances. No epidemiological studies have measured the evolution of the contributing of each of these athlete origin groups from $100 \mathrm{~m}$ to the marathon.

Method Speed, morphology and geographic origin of the Top 100 male and female athletes (from $100 \mathrm{~m}$ to the marathon) were collected and analyzed over the 1996-2012 period.

Results The amount of male sprinters $(100 \mathrm{~m}, 200 \mathrm{~m}$ and $400 \mathrm{~m})$ originating from West Africa increased from $57.7 \%$ in 1996 to $72.3 \%$ in 2012, while female sprinters from West Africa increased from $55 \%$ to $65 \%$ over the same period. This contribution has gradually increased from $400 \mathrm{~m}$ to $100 \mathrm{~m}$ for both sexes. For long distance events (3000m, 10000m and marathon), male athletes from East Africa represented $32 \%$ in 1996, which increased to $65.7 \%$ in 2012 and increased over the same period from $9 \%$ to $39 \%$ for women. In addition, male and female sprinters originating from West Africa have a significantly higher $(p<0.05) \mathrm{BMI}$ than athletes of other geographic origin. Conversely, long distances runners' BMI are significantly lower for runners with an East African origin $(p<0.05)$.

Conclusions The best performances are dominated by a few groups including the West African ancestry for the sprint distances and East African runners for the long distances. This dominance is strengthened from 1996 to 2012 for both sexes to the detriment of Caucasian and Asian athletes.

Keywords: Track and Field, geographical origin, sprint, long distance

Heading title: Geographical domination in Track and Field 


\section{INTRODUCTION:}

Culture and race in sports have always been disputed ${ }^{1}$. An understanding of these intertwined performance factors requires historical, psychological and biological considerations. High level performance remains multifactorial and depends on endogenous factors such as physiology, genetics, biometrics ${ }^{2,3}$, as well as exogenous parameters ${ }^{4-6}$. The geographical origin of athletes is a factor affected by both endo and exogenous components, which is believed to involve components influencing the gap between the highest steps of the podium. These determining components include the athlete's genetic, physiological, morphological and cultural inheritance.

In marathon, Marc et al assessed in the annual top 100the proportion of runners in relation to their native world regions. The proportion of native runners from Kenya and Ethiopia increased from $16 \%$ in 1990 to $94 \%$ in $2011^{7}$.According to Charles and Bejan ${ }^{8}$, the geographical origin is an integral part of the speed evolution phenomenon in modern athletics: runners of African origin possess the most world records in track and field. Indeed, anthropometric and biological studies ${ }^{9}$ have demonstrated that systematic differences exist among athletes of different origins. The amount of published evidence is significant: anthropometrically, Africans have longer lower limbs than Caucasians ${ }^{10}$, with smaller calf circumferences, their centre of mass is located higher in comparison to individuals of the same height ${ }^{11}$. Asians and Caucasians have longer torsos, with a lower centre of mass ${ }^{8}$. These genetic, physiological, and morphological factors, partially dependant on geographical origin, could cause advantages during race events.

The purpose of this study is to analyse the effect of geographical origin and its evolution in Track and Field events on the entire spectrum of Olympics distances from $100 \mathrm{~m}$ to the marathon. 


\section{METHODS:}

\section{Data:}

This is an epidemiological cross-sectional study of the top 100 world performances in athletic running events from 1996 to 2012. Data on mass, height, body mass index (BMI), speed, birth date, citizenship, and annual ranking were collected for each international top 100 ranked male and female athlete for eight Track and Field categories: 100m, 200m, 400m, $800 \mathrm{~m}, 1500 \mathrm{~m}, 3000 \mathrm{~m}, 10,000 \mathrm{~m}$ and marathon during the seasons 1996 to 2012 . This represented 27,200 annualperformers and 7,325 athletes worldwide: 4,003 males and 3,322 females.

Height and mass values were combined with the individual's best performance every year. All data were collected from the website http://www.tilastopaja.org and cross-classified by the International Association of Athletics Federations website: http://www.iaaf.org.

\section{Geographical origin}

The citizenship and direct ascendants of each athlete were investigated and classified into eight origin groups: West African, Afro-Americans, Caribbean, East African, North African, Euro-American, Asian, and Others origin.

"West Africans" are athletes who have West African nationality and possess at least one parent of West African nationality. "Afro-Americans" are athletes who have an American nationality and possess at least one parent who is of African origin (who could certainly be of West African descent). "Caribbean" are athletes who have a Caribbean nationality and possess at least one Caribbean parent who is of West African origin. "East Africans" are athletes who have an East African nationality and possess at least one parent of East African nationality. "North Africans" are athletes who have a North African nationality and possess at least one parent of North African nationality. "Euro-Americans" are athletes who have a European or American nationality and possess a Caucasian parent. 
"Asians" are athletes who have an Asian nationality and possess an Asian parent. The group from "Others origin" include the Middle East, South America, South Africa and Oceania.

\section{Morphology}

For men and women, the mean height, mass and BMI, and standard deviation were calculated for the world regions that dominate the sprint events. BMI of AfroAmerican, Caribbean and West African sprint runners were compared to the other athletes (in light of their dominance in the 100, 200 and 400m). The same method was applied in long distance events for east African runners (in light of their dominance in the $3000 \mathrm{~m}, 10,000 \mathrm{~m}$ and marathon). Their biometrical characteristics were compared to those of runners from other regions.

\section{Statistical analysis}

Statistical analysis was performed in R software v2.14.0. Statistical significance was considered at $p<0.05$. For each year and for both sexes, the contribution of each world region in the Top 100 was calculated as a percentage. Percentages of each group representation inside the top 100 between 1996 and 2012 were compared by $\mathrm{x} 2$ test. BMI was statistically compared between groups of athletes by Students t-tests.

Ethics Committee approval: We did not need any ethics committee approval because we collected all data from websites. 


\section{RESULTS:}

\section{Geographical distribution}

27,200 athletes performed in running events annually between 1996 and 2012 . During this period, the top 100 in the sprint events (100, 200 and 400m) were dominated by Afro-North American, Caribbean, and West African runners. Over the total period, these three groups represented $63 \%$ for men and $58.5 \%$ for women (Figure 1).
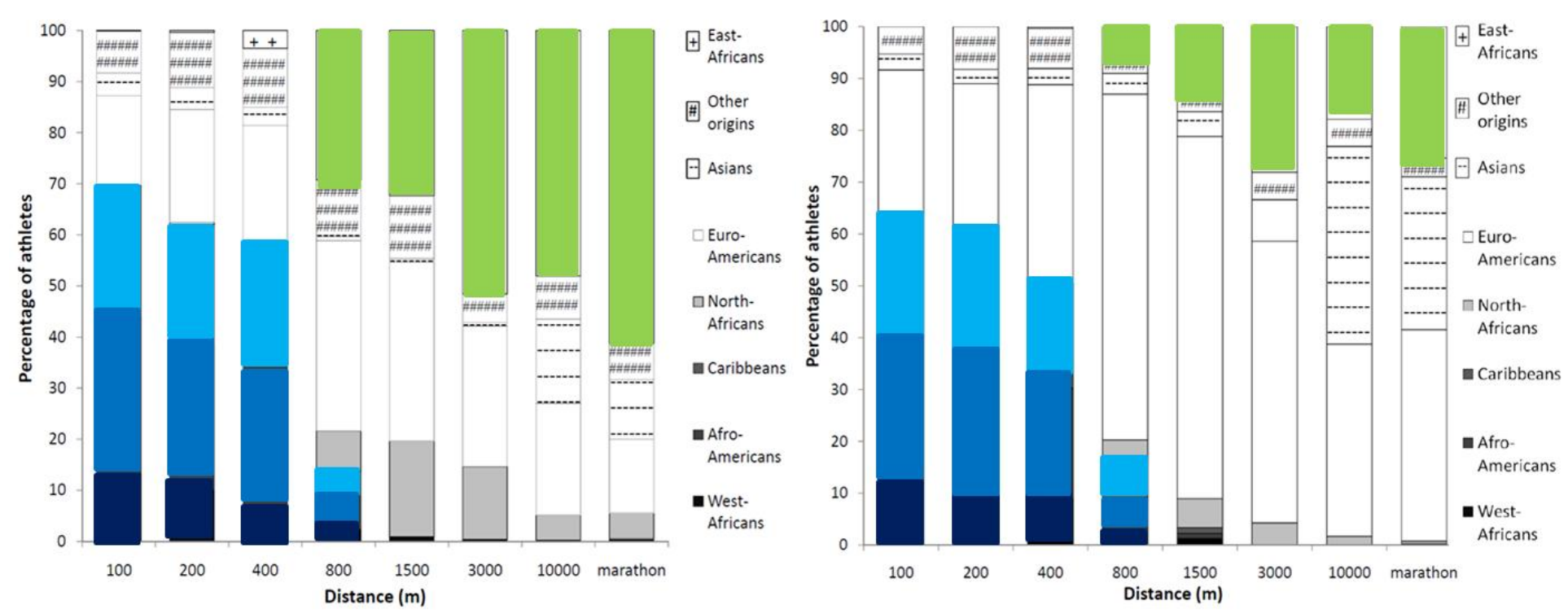

Figure 1. Percentage distribution of Top 100 athletes by Track and Field event depending on their geographical origins. (A) Men from 1996 to 2012, (B) Women from 1996 to 2012.

Men's long-distance events $(3000 \mathrm{~m}, 10,000 \mathrm{~m}$ and marathon) are dominated by East African runners -representing 53.6\% (Figure 1A). In women's long-distance events the contribution by world region is more heterogeneous among East African, Asian and European women; respectively $23.8 \%, 25.2 \%$ and $35.9 \%$ (Figure 1B). In addition, a gradient effect concerning the dominating groups is observed depending on the event.

The three dominating groups for sprint events (Afro-American, Caribbean and West African origin) are $69.5 \%$ for the $100 \mathrm{~m}, 61.9 \%$ for the $200 \mathrm{~m}, 57.7 \%$ for the $400 \mathrm{~m}$ and only $13.6 \%$ for the $800 \mathrm{~m}$ (Figure $1 \mathrm{~A}$ ). For women, the same trend is observed with a contribution of these groups representing $64 \%$ for the $100 \mathrm{~m}$, 
$60.7 \%$ for the $200 \mathrm{~m}, 50.6 \%$ for the $400 \mathrm{~m}$ and $16.1 \%$ for the $800 \mathrm{~m}$ (Figure $1 \mathrm{~B}$ ). For both sexes, after the $800 \mathrm{~m}$ these origin groups were almost absent from the Top 100.

Concerning long distance events, East African male runners represented 29.3\% for the $800 \mathrm{~m}, 32.3 \%$ for the $1500 \mathrm{~m}, 51.6 \%$ for the $3000 \mathrm{~m}, 48.1 \%$ for the $10,000 \mathrm{~m}$ and $61.3 \%$ for the marathon (Figure $1 \mathrm{~A}$ ). For East African women, a similar gradient with the distance is also evident, increasing from $4.6 \%$ in the $800 \mathrm{~m}$ to $25.4 \%$ in the marathon (Figure 1B).

For men, the comparison between 1996 and 2012 reveals a significant $(p<0.01)$ strengthening of these gradients with distance: Afro-Americans, Caribbean and West Africans' representation increase in sprint events and East African involvement increases on long distance events (Figure 2). Afro-Americans, Caribbean and West Africans' represented $61 \%, 53 \%$ and $59 \%$ for the $100 \mathrm{~m}$, $200 \mathrm{~m}$ and $400 \mathrm{~m}$ in 1996 (mean of $57.7 \%$ ) and in 2012, 82\%, 71\% and 64\% respectively (mean of $72.3 \%$ ).
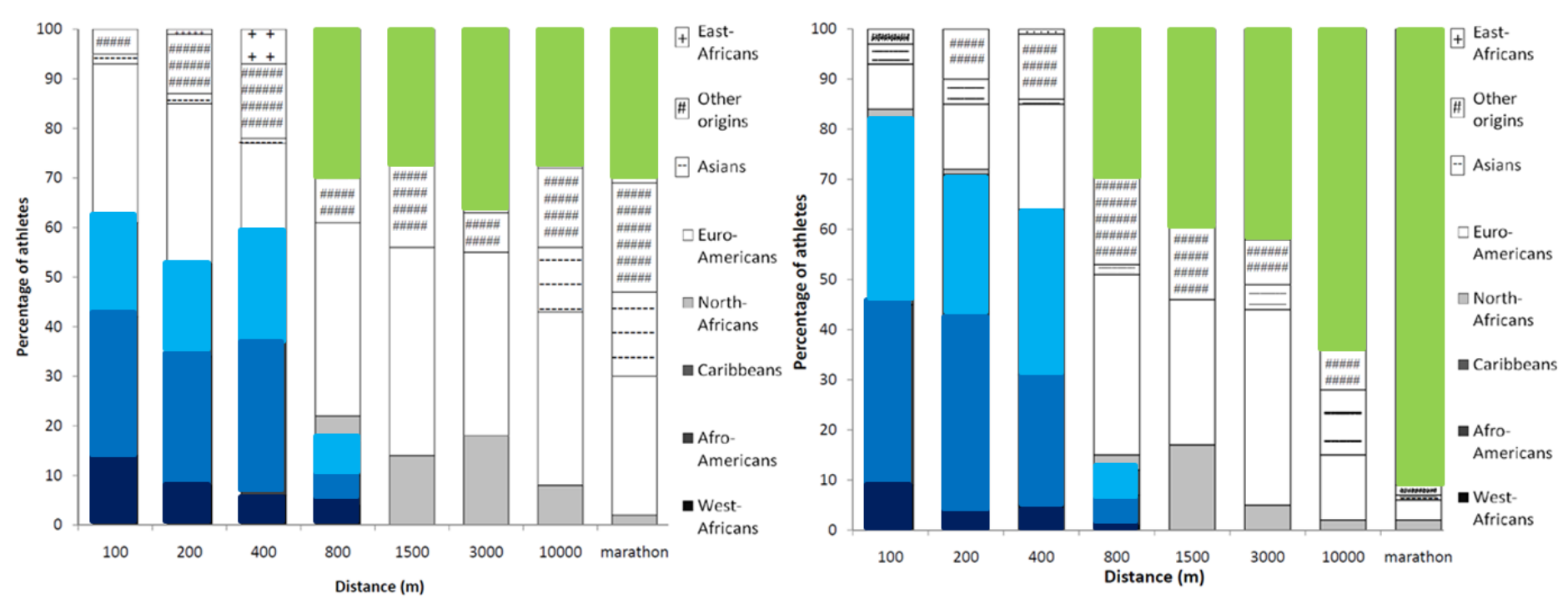

Figure 2.Percentage distribution of men athletes by Track and Field event depending on their geographical origins. (A) Top 100 in 1996, (B) Top 100 in 2012.

For the long distance events $(3000 \mathrm{~m}, 10,000 \mathrm{~m}$ and marathon), native runners from East Africa participate significantly $(p<0.01)$ more and more, $32 \%$ athletes in 1996 and $65,7 \%$ in 2012 (Figure 2). Detailed by event, these runners represented $37 \%, 28 \%$ and $31 \%$ for the $3000 \mathrm{~m}, 10,000 \mathrm{~m}$ and marathon in 1996 (mean of 32\%) and in 2012 42\%, 64\% and 91\% respectively (mean of $65.7 \%)$ (Figure 2). 
Consequently, the share of other runners (Asians, Euro-Americans, North Africans, and the Other origins) has largely decreased from 68\% in 1996 down to $34.3 \%$ in 2012.

The domination of Afro-American, Caribbean and West African women has also significantly $(p<0.01)$ increased accounting for $57 \%, 53 \%$ and $55 \%$ in 1996 for the $100 \mathrm{~m}, 200 \mathrm{~m}$ and $400 \mathrm{~m}$ (mean of $55 \%$ ) and in 2012 for $74 \%, 66 \%$ and $55 \%$ for the same events respectively (mean of 65\%)(Figure 3). In contrast, EuroAmericans' share decreased from $34.7 \%$ to $28.6 \%$ during the same period.
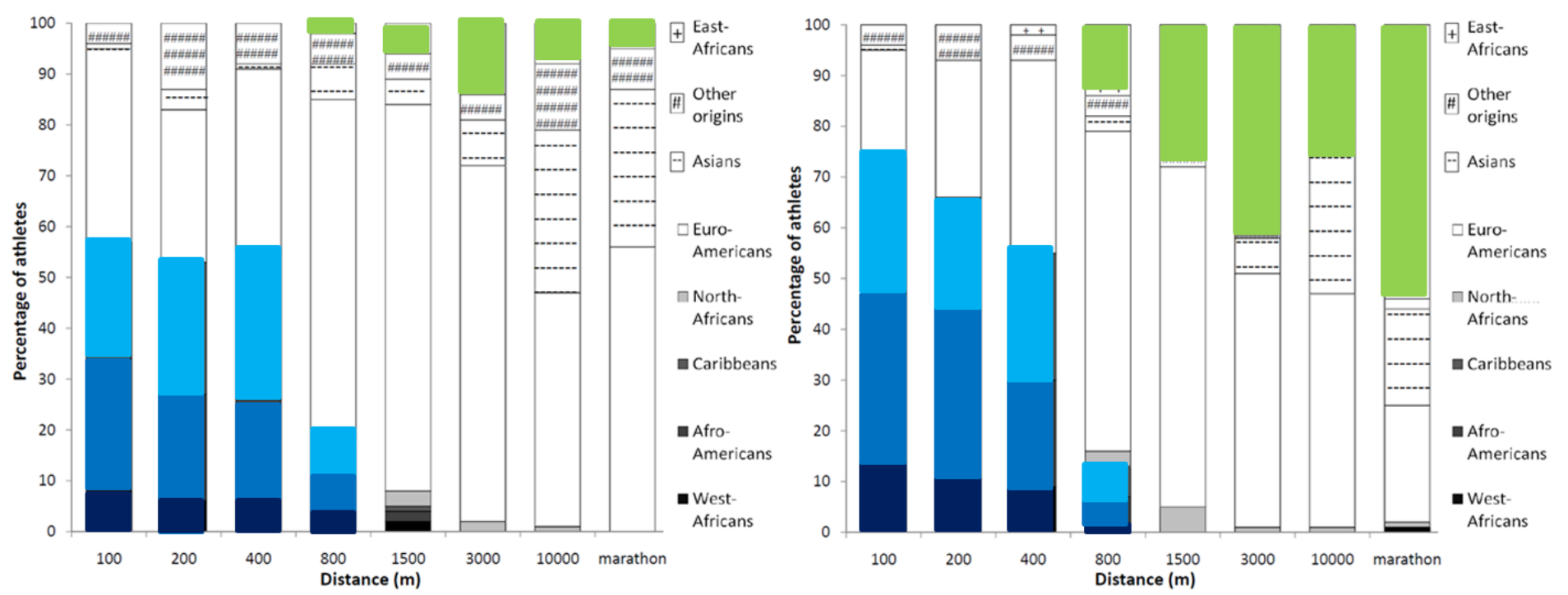

Figure 3. Percentage distribution of women athletes by Track and Field event depending on their geographical origins. (A) Top 100 in 1996, (B) Top 100 in 2012.

On long distance events, East African women runners have also significantly increased. They represented in 1996, 14\%, $8 \%$ and $5 \%$ in $3000 \mathrm{~m}, 10,000 \mathrm{~m}$ and marathon respectively (mean of long distance: $9 \%$ ). In 2012, East African runners represent $41 \%, 21 \%$ and $54 \%$ for the same events respectively (mean of $39 \%$ ). Consequently, the number of Top 100 Euro-American and Asian women runners decreased. Euro-American athletes represented $57 \%$ in

1996 and $40 \%$ in 2012. At the same time, Asian runners' share decreased from $24 \%$ to $18 \%$. 


\section{Morphological differences}

During the study period, the Afro-American, Caribbean and West African athletes, who dominate sprint events, have a significantly higher BMl than all the other athletes $(p<0.05)$ and this for both sexes (Figures $4 A$ and $4 B)$. For men, the mean $\mathrm{BMI}$ of athletes of the three best regions are $23.5 \pm 1.7 \mathrm{~kg} \cdot \mathrm{m}^{-2}, 23.2 \pm 1.6$ $\mathrm{kg} \cdot \mathrm{m}^{-2}$ and $22.5 \pm 1.3 \mathrm{~kg} \cdot \mathrm{m}^{-2}$ for the $100 \mathrm{~m}, 200 \mathrm{~m}$ and $400 \mathrm{~m}$ respectively, compared to the other athletes who have a mean BMl of $22.9 \pm 1.6 \mathrm{~kg} \cdot \mathrm{m}^{-2}, 22.5 \pm$ $1.5 \mathrm{~kg} \cdot \mathrm{m}^{-2}$ and $21.9 \pm 1.3 \mathrm{~kg} \cdot \mathrm{m}^{-2}$ for the same distance respectively (Figure $4 \mathrm{~A}$ ).
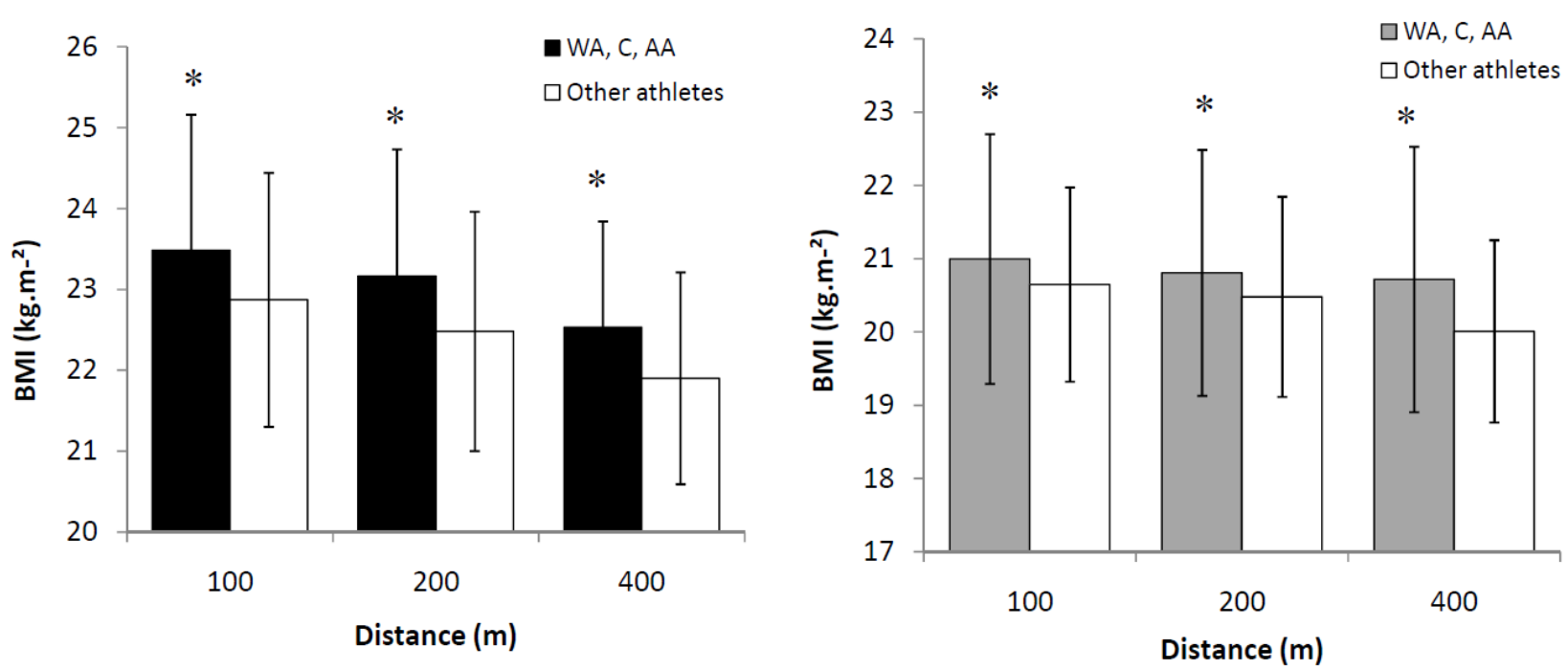

Figure 4. Mean BMI and standard deviation for the three best represented regions in sprint (West African, Caribbean and Afro-American) compared to the mean BMI and standard deviation of all the others athletes coming from the Top 100 from 1996 to 2012. (A) Men (B) Women, $* \mathrm{P}<0.05$ for group Other athletes.

For women, the mean BMI of athletes from the three highest represented regions are $21 \pm 1.7 \mathrm{~kg} \cdot \mathrm{m}^{-2}, 20.8 \pm 1.7 \mathrm{~kg} \cdot \mathrm{m}^{-2}$ and $20.7 \pm 1.2 \mathrm{~kg} \cdot \mathrm{m}^{-2}$ for the $100 \mathrm{~m}, 200 \mathrm{~m}$ and $400 \mathrm{~m}$ respectively, compared to the other athletes who have a mean BMl of $20.6 \pm 1.3 \mathrm{~kg} \cdot \mathrm{m}^{-2}, 20.5 \pm 1.4 \mathrm{~kg} \cdot \mathrm{m}^{-2}$ and $20 \pm 1.2 \mathrm{~kg} \cdot \mathrm{m}^{-2}$ for the same distance respectively (Figure 4B).

For long distance events (3000m, 10,000m and marathon) the BMI of East African men is significantly lower than other runners. Their mean BMl are $19.6 \pm 1.1 \mathrm{~kg} . \mathrm{m}^{-}$ ${ }^{2}, 19.3 \pm 1.1 \mathrm{~kg} \cdot \mathrm{m}^{2}$ and $19.5 \pm 1.3 \mathrm{~kg} \cdot \mathrm{m}^{-2}$ for $3000 \mathrm{~m}, 10,000 \mathrm{~m}$ and marathon respectively, compared to the rest of the athletes who have a mean BMl of $19.9 \pm$ $1.1 \mathrm{~kg} \cdot \mathrm{m}^{-2}, 19.7 \pm 1.2 \mathrm{~kg} \cdot \mathrm{m}^{-2}$ and $19.6 \pm 1.2 \mathrm{~kg} \cdot \mathrm{m}^{-2}$ for the same distance respectively (Figure 5A). 

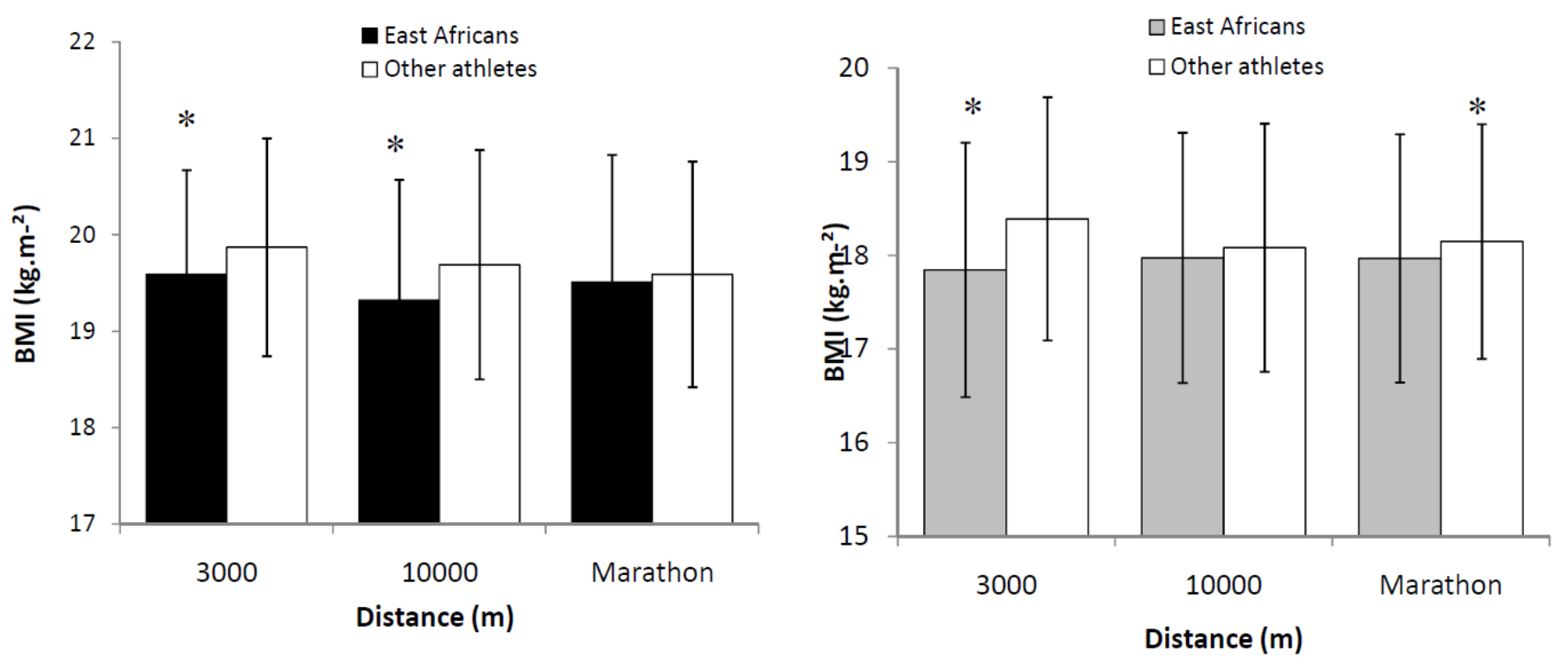

Figure 5. Mean BMI and standard deviation for the most represented long distance athletes (East African) compared to the mean BMI and standard deviation of all the others athletes coming from the Top 100 from 1996 to 2012. (A) Men (B) Women, $* \mathrm{P}<0.05$ for group Other athletes.

For women, the trend is the same for East African women runners with a mean BMI of $17.8 \pm 1.4 \mathrm{~kg} \cdot \mathrm{m}^{-2}, 18 \pm 1.3 \mathrm{~kg} \cdot \mathrm{m}^{-2}$ and $18 \pm 1.3 \mathrm{~kg} \cdot \mathrm{m}^{-2}$ for $3000 \mathrm{~m}, 10,000 \mathrm{~m}$ and marathon respectively, compared to the rest of the runners (all the others), who have a mean BMl of $18.4 \pm 1.3 \mathrm{~kg} \cdot \mathrm{m}^{-2}, 18.1 \pm 1.3 \mathrm{~kg} \cdot \mathrm{m}^{-2}$ and $18.2 \pm 1.3 \mathrm{~kg} \cdot \mathrm{m}^{-}$ ${ }^{2}$ for the same distance respectively (Figure $5 B$ ). 


\section{DISCUSSION}

Our study is the first to describe the geographical origin of the Top 100 male and female Track and Field athletes, and to characterize its evolution over the past two decades.

This study shows that race events are increasingly being dominated by a specific geographical group of origin and this phenomenon appears to strengthen with time. In fact, these genetic, physiological, cultural, and morphological factors, which partially depend on geographical origins, could be advantageous in accordance with the race type, and consequently, for the effort characteristics and constraints.

\section{West Africans and sprint performance}

Concerning sprint distances $(100 \mathrm{~m}, 200 \mathrm{~m}$ and $400 \mathrm{~m})$, runners with AfroAmerican, Caribbean and West African origins dominate, and this tendency has strengthened over time. From a genetic perspective, a previous study ${ }^{12}$ showed that specific genes, such as ACTN3 (a-Actinin-3), could be associated with elite athletic performance, demonstrating that male and female elite sprint athletes have significantly higher frequencies of the 577R allele than the general population. The ACTN3 gene, specifically expressed in fast twitch myofibers, allows for the generation of force at a higher velocity.

Furthermore, our study shows that there are also morphological differences between the West African descendant sprinters, and the other Top 100 runners. For both sexes, mean BMl is significantly higher for sprinters with West African origins. Sedeaud et al. $^{13}$ demonstrated that, physiological, physical and biomechanical constraints generated morphologies adapted to the event and that BMI appeared as a useful indicator of "embedded energy" for elite athletes' running capabilities. It was shown that elite sprinters are heavier and that higher

$\mathrm{BMI}$ and mass are associated with their need of higher energy outputs. This corresponds to a maximisation of the anaerobic metabolism, the main mechanism involved in total energy 
requirements for $100 \mathrm{~m}$ sprints ${ }^{14}$. Indeed, ATP concentration is dependent on muscle mass, and athletes' BMI represents an indication of the power reserve related to lean mass ${ }^{15,16}$. Thus the possible progression in speed would be present in muscle mass increments ${ }^{17}$ and BMI optimisation ${ }^{13}$. Furthermore, in 2005, Babel et al. ${ }^{18}$ demonstrated that the stride number/body height ratio could be used to predict sprint performance in Afro-Caribbean children and consequently showed that the fastest runners were those with this lowest ratio. In addition, many authors have also demonstrated the relationships between stride length, ground contact time, and sprint performance ${ }^{19,20}$. Moreover, to run faster, the key is not to move quicker, but to applying greater support forces on the ground ${ }^{21}$. The greater BMl of the top sprinters (with Afro-American, Caribbean and West African origins) demonstrated in this study is consistent with the trend of $\mathrm{BMI}$ and speed increase observed in the top 100 for all the spectrum of track and field distances ${ }^{13}$.

\section{East Africans and long distance performance}

In contrast, East African runners dominate on long distance events, which showed to be an annually reinforced gradient. An epidemiological study ${ }^{7}$ identified factors that influence best performances in the marathon, considering historical, demographic, anthropometrical and seasonal characteristics for the 100 yearly best performers from 1990 to 2011. This study confirmed the East African domination and showed that body mass, height and BMI have decreased since 1990 to reach optimal values in 2012 of $56.4 \mathrm{~kg}, 170.4 \mathrm{~cm}$ and BMI of 19.42 $\mathrm{kg} \cdot \mathrm{m}^{-2}$.

One explanatory factor for this dominance could be physiological characteristics. Despite comparable maximum oxygen uptake, Africans tend to run at a higher running economy than 
Europeans ${ }^{22,23}$. Kenyan runners also have greater $\beta$-oxidative enzyme HAD activity (3-hydroxyacyl- Co A-dehydrogenase activity) in the muscles ${ }^{24,25}$.

Furthermore, Onywera et al ${ }^{26}$ reported that Kenyan runners differed from the general population due to greater physical activity during childhood and adolescence on their travels to school. A higher proportion of athletes ran to school every day (controls $22 \%$, national athletes $73 \%$ and international athletes $81 \%)$ and covered greater distances than other groups. It has been shown that Kenyan boys who travelled to school by walking and running had $30 \%$ greater VO2 max than those who did not ${ }^{27}$. Similar results are seen for Ethiopian runners ${ }^{28}$. Also, high altitude exposure, as experienced by many young East African runners, combined synergistically with endurance training to induce haematological adaptations, also account for greater physiological capabilities ${ }^{29}$.

However, East African female runners' superiority is not as strongly established as for men (in 2012, $54 \%$ for women as opposed to $91 \%$ in men). This difference can be explained by their later arrival in this event; their first appearance in the marathon occurred in 1984 in the Los Angeles Olympic Games ${ }^{30}$.

Our study highlighted the presence of geographical gradients depending on the race distance. The West African ancestry (Afro-American, Caribbean and West African) sprinters dominate sprint events with a negative gradient from $100 \mathrm{~m}$ to $400 \mathrm{~m}$, and are totally absent after the $800 \mathrm{~m}$ for both sexes. In contrast, the male and female East African runners dominate the long distances with a positive gradient from $800 \mathrm{~m}$ to the marathon. Such a gradient has already been observed in other domains such as morphology ${ }^{13}$ and energetic contribution ${ }^{14}$.

In addition, Sedeaud and al ${ }^{13}$ have demonstrated that gradient of physiques such as body mass, height and body mass index are ordered and decrease progressively with distance from $100 \mathrm{~m}$ to the marathon. These authors highlighted the importance of the biometrics in Track 
and Field performance by identifying performance organisation through optimal morphological intervals. Moreover, links between performance and morphology are strengthened by gradient of size within each discipline. For example, sprinters are not only heavier than their long and middle distances counterparts but within their distance, the fastest athletes are also the heaviest ones. In contrast, the best long distance runners have a lower mass and BMl compared to less rapid athletes ${ }^{13}$. In their study ${ }^{14}$ Ward and Smith show the existence of gradient contribution from the anaerobic and aerobic mechanisms to the total energy requirements from $100 \mathrm{~m}$ to $10,000 \mathrm{~m}$. This mathematical model affirmed a gradual decrease of anaerobic measurements with race distance and a gradual increase of aerobic contribution from the $100 \mathrm{~m}(7 \%)$ to the $10,000 \mathrm{~m}(96 \%)$.

\section{What Does This Article Add?}

This study intends to reach sports scientists, and sports staff who may find support to select and optimize the morphological parameters of athletes to reach their best level.

A significant morphological gap $(p<0.05)$ is visible between the athletes dominating the sprint or the long distances events in relation to the other nationalities in the Top 100 for both sexes.

Running events such as the $800 \mathrm{~m}, 1,500 \mathrm{~m}$ and $3,000 \mathrm{~m}$ are demographically more heterogeneous, with more nationalities represented as opposed to sprint or long distance events.

Thus, the middle distances appear to be the most accessible events to a greater range of nationalities.

However, these demographic and morphological results may be restrained only to the highest level in Track and Field events. 


\section{CONCLUSION}

This study reveals the distribution of Top 100 athletes depending on their geographical origins. On the whole race events spectrum, the best performances are dominated by a few groups of West African ancestry for the sprint distances and East African runners for the long distance. This dominance has strengthened from 1996 to 2012 for both sexes to the detriment of Caucasian and Asian athletes who are less present on international podiums. The expression of multiple optimum values of biometrical, energetic parameters depending on the events is visible on the gradual contribution of these athletes with distance.

Conflicts of Interest and Source of Funding: all authors declare having no conflict of interest. The authors have not received funding for this work specifically; the Institute receives yearly funding from the French Ministry of Health, Youth, and Sports. 


\section{BIBLIOGRAPHY}

1. Miles LR. Review of Entine, Jon, Taboo: Why Black Athletes Dominate Sports and Why We're Afraid to Talk About It. June 2001. Available at: http://www.h-net.org/reviews/showrev.php?id=5265. Accessed November 28, 2013.

2. Lippi G, Favaloro EJ, Guidi GC. The genetic basis of human athletic performance. Why are psychological components so often overlooked? J. Physiol. (Lond.) 2008;586(Pt 12):3017; author reply 3019-3020. doi:10.1113/jphysiol.2008.155887.

3. Macarthur DG, North KN. Genes and human elite athletic performance. Hum. Genet. 2005;116(5):331-339. doi:10.1007/s00439-005-1261-8.

4. El Helou N, Tafflet M, Berthelot G, Tolaini J, Marc A, Guillaume M, Hausswirth C, Toussaint J-F. Impact of Environmental Parameters on Marathon Running Performance. PLOS ONE 2012;7(5):e37407. doi:10.1371/journal.pone.0037407.

5. Ely MR, Cheuvront SN, Roberts WO, Montain SJ. Impact of weather on marathon-running performance. Med Sci Sports Exerc 2007;39(3):487-493. doi:10.1249/mss.0b013e31802d3aba.

6. Vihma T. Effects of weather on the performance of marathon runners. Int J Biometeorol 2010;54(3):297-306. doi:10.1007/s00484-009-0280-x.

7. Marc A, Sedeaud A, Guillaume M, Rizk M, Schipman J, Antero-Jacquemin J, Haida A, Berthelot G, Toussaint JF. Marathon progress: demography, morphology and environment. Journal of Sports Sciences. doi:10.1080/02640414.2013.835436.

8. Charles JD, Bejan A. The evolution of speed, size and shape in modern athletics. J Exp Biol 2009;212(15):24192425. doi:10.1242/jeb.031161.

9. Marino FE, Lambert MI, Noakes TD. Superior performance of African runners in warm humid but not in cool environmental conditions. J. Appl. Physiol. 2004;96(1):124-130. doi:10.1152/japplphysiol.00582.2003.

10. Fernández JR, Heo M, Heymsfield SB, Pierson RN Jr, Pi-Sunyer FX, Wang ZM, Wang J, Hayes M, Allison DB, Gallagher D. Is percentage body fat differentially related to body mass index in Hispanic Americans, African Americans, and European Americans? Am. J. Clin. Nutr. 2003;77(1):71-75.

11. Wagner DR, Heyward VH. Measures of body composition in blacks and whites: a comparative review. Am. J. Clin. Nutr. 2000;71(6):1392-1402.

12. Yang N, MacArthur DG, Gulbin JP, Hahn AG, Beggs AH, Easteal S, North K. ACTN3 genotype is associated with human elite athletic performance. Am. J. Hum. Genet. 2003;73(3):627-631. doi:10.1086/377590.

13. Sedeaud A, Marc A, Dor F, Marck A, Schipman J, Dorsey M, Haida A, Berthelot G, Toussaint J-F. BMI, a performance parameter for speed improvement. Plos One.

14. Ward-Smith AJ. A mathematical theory of running, based on the first law of thermodynamics, and its application to the performance of world-class athletes. J Biomech 1985;18(5):337-349.

15. Nevill AM, Winter EM, Ingham S, Watts A, Metsios GS, Stewart AD. Adjusting athletes' body mass index to better reflect adiposity in epidemiological research. J Sports Sci 2010;28(9):1009-1016. doi:10.1080/02640414.2010.487071.

16. Watts AS, Coleman I, Nevill A. The changing shape characteristics associated with success in world-class sprinters. J Sports Sci 2012;30(11):1085-1095. doi:10.1080/02640414.2011.588957.

17. Weyand PG, Davis JA. Running performance has a structural basis. J. Exp. Biol. 2005;208(Pt 14):2625-2631. doi:10.1242/jeb.01609.

18. Babel K, Hertogh $\mathrm{C}$, Hue O. Influence of ethnic origin on predictive parameters of performance in sprint running in prepubertal boys. Int J Sports Med 2005;26(9):798-802. doi:10.1055/s-2004-830562.

19. Coh M, Milanović D, Kampmiller T. Morphologic and kinematic characteristics of elite sprinters. Coll Antropol 2001;25(2):605-610.

20. Mercer JA, Vance J, Hreljac A, Hamill J. Relationship between shock attenuation and stride length during running at different velocities. Eur. J. Appl. Physiol. 2002;87(4-5):403-408. doi:10.1007/s00421-002-0646-9.

21. Weyand PG, Sternlight DB, Bellizzi MJ, Wright S. Faster top running speeds are achieved with greater ground forces not more rapid leg movements. J. Appl. Physiol. 2000;89(5):1991-1999. 
22. Bosch AN, Goslin BR, Noakes TD, Dennis SC. Physiological differences between black and white runners during a treadmill marathon. Eur J Appl Physiol Occup Physiol 1990;61(1-2):68-72.

23. Larsen HB. Kenyan dominance in distance running. Comp. Biochem. Physiol., Part A Mol. Integr. Physiol. 2003;136(1):161-170.

24. Saltin B, Kim CK, Terrados N, Larsen H, Svedenhag J, Rolf CJ. Morphology, enzyme activities and buffer capacity in leg muscles of Kenyan and Scandinavian runners. Scand J Med Sci Sports 1995;5(4):222-230.

25. Weston AR, Karamizrak O, Smith A, Noakes TD, Myburgh KH. African runners exhibit greater fatigue resistance, lower lactate accumulation, and higher oxidative enzyme activity. J. Appl. Physiol. 1999;86(3):915923.

26. Onywera VO, Scott RA, Boit MK, Pitsiladis YP. Demographic characteristics of elite Kenyan endurance runners. J Sports Sci 2006;24(4):415-422. doi:10.1080/02640410500189033.

27. Saltin B, Larsen H, Terrados N, Bangsbo J, Bak T, Kim CK, Svedenhag J, Rolf CJ. Aerobic exercise capacity at sea level and at altitude in Kenyan boys, junior and senior runners compared with Scandinavian runners. Scand J Med Sci Sports 1995;5(4):209-221.

28. Scott RA, Georgiades E, Wilson RH, Goodwin WH, Wolde B, Pitsiladis YP. Demographic characteristics of elite Ethiopian endurance runners. Med Sci Sports Exerc 2003;35(10):1727-1732. doi:10.1249/01.MSS.0000089335.85254.89.

29. Schmidt W, Heinicke K, Rojas J, Manuel Gomez J, Serrato M, Mora M, Wolfarth B, Schmid A, Keul J. Blood volume and hemoglobin mass in endurance athletes from moderate altitude. Med Sci Sports Exerc 2002;34(12):1934-1940. doi:10.1249/01.MSS.0000041225.34124.98.

30. O'Brien M. Women and sport. Applied Ergonomics 1985;16(1):25-39. doi:10.1016/0003-6870(85)90144-9. 